\title{
Development and Application of Biological Preparations against Infectious Diseases of Cattle and Poultry
}

\author{
Tsovinar R Balabekyan, Flora N Tkhruni and Kristina J Karapetyan* \\ Laboratory of Food Biological Safety at Scientific and Production Center "Arm biotechnology" NSPO, National Academy of Science. Republic of Armenia \\ Submission: April 30, 2019; Published: May 17, 2019 \\ *Corresponding author: Laboratory of Food Biological Safety at Scientific and Production Center "Arm biotechnology" NSPO, National Academy of \\ Science. Republic of Armenia
}

Keywords: Lactic acid bacteria; Probiotics; Multidrug resistance; Salmonellosis

\section{Mini Review}

The main problems that may emerge in the cattle and poultry industry are antibiotic resistant microorganisms on the one hand and the control of treatment of intestinal infections without antibiotic use. In order to improve the health of animals and birds need to regularly monitor immune status of organism usage of antimicrobial agents with caution and, at the same time to exclude ineffective application of antibiotics. A course of antibiotics affects all bacteria, not just those that are the cause of disease. It is therefore important to use antibiotics in the correct way and only when necessary. This will minimize the problem of resistance, so that the antibiotics available still work when they are needed and also in order to maintain a healthy gut microbiota [1]. Poultry birds have frequently been incriminated as a mean of Salmonella contamination and consequently act as major source of the pathogen in humans. This organism has been isolated from a range of foods in almost every country.

This Salmonella and Campylobacter are the most common causes of zoonotic food borne infections. Antimicrobial resistance was detected commonly in isolates from human cases as well as from food-producing animals and food in the European Union (EU). Almost half of the isolates from clinical cases were resistant to at least one antimicrobial and $28.9 \%$ were multidrug-resistant. Multidrug resistance exhibited by Salmonella strains has proved to be a big hurdle in the development of an effective anti-Salmonella therapy [2]. The multidrug-resistant (MDR) phenotypes of Salmonella enterica may carry their resistance determinants on chromosomal locations, on resistance plasmids, or on both [3]. Salmonella enteritidis are important food-borne pathogens noted for causing millions of cases of food-borne illness, diarrhea, small intestinal inflammation in the United States, European countries. The major source of infection is food, poultry meat, eggs. Recent studies have found that in certain Enterobacteriaceae, including Salmonella, virulence genes may be co localizing on transferable resistance plasmids, a phenomenon that would lend credence to studies that have shown that antimicrobial-resistant Salmonella strains may be more invasive than Salmonella strains that are susceptible to antimicrobials.

The food supply, including poultry products, may transmit antimicrobial drug-resistant Escherichia coli to humans. Acquired resistance to first-line antimicrobial agents increasingly complicates the management of extra-intestinal infections due to Escherichia coli, which are a major source of illness, death, and increased healthcare costs [4]. One suspected source of drug-resistant $E$. coli in humans is use of antimicrobial drugs in agriculture. This use presumably selects for drug-resistant $E$. coli, which may be transmitted to humans through the food supply. Supporting this hypothesis is the high prevalence of antimicrobial drug-resistant $E$. coli in retail meat products, especially poultry, and the similar molecular characteristics of fluoroquinolone-resistant $E$. coli from chicken carcasses and from colonized and infected persons, in contrast to the marked differences between drug-susceptible and drug-resistant source isolates from humans.

In recent years, the frequency of food poisoning in Armenia, caused by dairy and meat products, has increased dramatically. According to the National Bureau of Expertise (Yerevan, RA) data, the main pathogens are Escherichia coli, Staphylococcus aureus species. The growing problem of the prevalence of pathogenic bacteria resistant to antibiotics, motivated to search alternative 
natural microbial preparations, including on the basis of probiotic lactic acid bacteria and its bacteriocins. The obtaining and investigation of biological properties of proteinoceous antibiotics, on the basis of probiotic lactic acid bacteria (LAB), shown, that bacteriocins, metabiotics and peptides of LAB represent bactericides have a broad range of activity and are excellent candidates for development of new prophylactic and therapeutic substances to complement or replace conventional antibiotics [5]. Thus, the increasing interest in these compounds has stimulated the isolation of new strains of probiotic LAB -bacteriocin producers and the characterization of novel peptides [6].

Bacteriocins are an interesting group of biomolecules with broad spectrum of antimicrobial activity. Some of their properties (significant potency, high stability, low toxicity, broad spectrum of activity) make them suitable compounds for using them as a basis for development of antimicrobial agents of new generation [3]. At the same time, bacteriocins were found to be safe for human consumption by the Food and Drug Administration. So, the continue development of new classes of natural antimicrobial agents, possessing antibacterial activity, has become of increasing importance for medicine and veterinary. In SPC "Arm biotechnology" the new strains of lactic acid bacteria were isolated and investigated. Their antimicrobial activity against antibiotic-resistant pathogenic bacteria, especially dangerous infections and pathogenic microorganisms, isolated from organs of infected animals and birds, was shown $[7,8]$. It was shown, that antimicrobial preparations, obtained from Lactobacillus rhamnosus 20-12 and Lactobacillus acidophilus 1991 LAB strains, during in vitro studies possesses bactericidal activity against pathogens isolated from the internal organs of animals. It was shown that the investigated lactic acid bacteria during growing synthesized bacteriocins (peptides) having different molecular weight Using of antimicrobial preparation, obtained after growth of L. acidophilus 1991 in the poultry farms for treatment of the birds infected with Salmonellosis shown, that it can be successfully implemented for the prophylaxis of animal infections instead of antibiotics. It was shown overweight of animals, absence of mortality [9].

\section{References}

1. Yoneyama H, Katsumata R (2006) Antibiotic resistance in bacteria and its future for novel antibiotic development. Biosci Biotechnol Biochem 70(5): 1060-1075.

2. European Food Safety Authority (EFSA) Journal (2014) 12(3): 3590 -3599 .

3. Ken-ichi Okuda, Zendo T, Sugimoto S (2013) Effect of bacteriocins on methicillin-resistant Staphilococcus aureus Biofilm. Antimicrobial agents and chemotherapy 57(11): 5572-5579.

4. Russo TA, Johnson JR (2003) Medical and economic impact of extraintestinal infections due to Escherichia coli: an overlooked epidemic. Microbes Infect 5: 449-456.

5. Kristiansen JE, Thomsen VF, Martins A, Viveiros M, Amaral L (2010) Non-antibiotics reverse resistance of bacteria to antibiotics. In Vivo 24: 751-754.

6. Cotter PD, Ross RP, Hill C (2013) Bacteriocins- A viable alternative to antibiotics.? Nat Ref Microbiol 11: 95-105.

7. Tkhruni FN (2016) Efficiency of metabiotics from lactic acid bacteria against pathogens. International Journal of Current Research and Academic Review 3: 1-11.

8. Israyelyan A, Karapetyan K, Tkhruni F, Arstamyan L, Balabekyan T (2015) Sensitivity of different pathogens to biological antimicrobial agents. European Journal of Biomedical and Life Sciences 3: 61-66.

9. Harutyunyan R, Tkhruni F, Aghajanyan A (2010) Treatment and / or prevention of pigs and poultry intestinal diseases. Patent RA, № 2378 A2.

Your next submission with Juniper Publishers
will reach you the below assets
- Quality Editorial service
- Swift Peer Review
- Reprints availability
- E-prints Service
- Manuscript Podcast for convenient understanding
- Global attainment for your research
- Manuscript accessibility in different formats
( Pdf, E-pub, Full Text, Audio)
- Unceasing customer service
Track the below URL for one-step submission
https://juniperpublishers.com/online-submission.php

